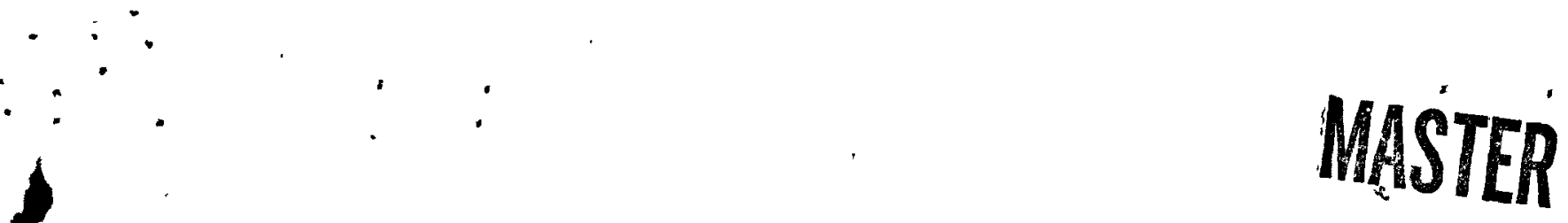

WANL-TME-046

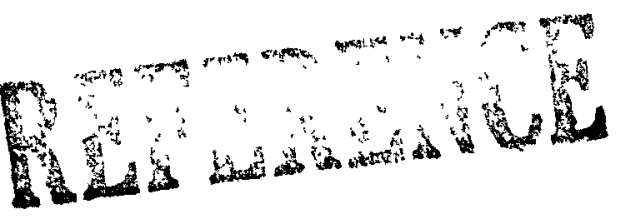

\title{
SURVEY OF RADIATION EFFECTS TESTING FACILITIES
}

\section{April 1962}

$+$

\footnotetext{
This report was prepared as an account of work sponsored by the United States Government. Nesther the United States nor the United States Energy Research and Development Administration, nor any of their employees, nor any of their contractors, their employees, nor any of their contractors,
subcontractors, or their employees, makes any subcontractors, or their employees, makes any
warranty, express or implied, or assumes any legal liability or responsibility for the accuracy, completeness or usefulness of any information, apparatus, product or process disclosed, or represents that its use would not infringe privately owned rights.
} 


\section{DISCLAIMER}

This report was prepared as an account of work sponsored by an agency of the United States Government. Neither the United States Government nor any agency Thereof, nor any of their employees, makes any warranty, express or implied, or assumes any legal liability or responsibility for the accuracy, completeness, or usefulness of any information, apparatus, product, or process disclosed, or represents that its use would not infringe privately owned rights. Reference herein to any specific commercial product, process, or service by trade name, trademark, manufacturer, or otherwise does not necessarily constitute or imply its endorsement, recommendation, or favoring by the United States Government or any agency thereof. The views and opinions of authors expressed herein do not necessarily state or reflect those of the United States Government or any agency thereof. 


\section{DISCLAIMER}

Portions of this document may be illegible in electronic image products. Images are produced from the best available original document. 


\section{ASTRONUCLEAR LABORATORY}

Dr. A. Boltax

Mr. G. Grandy

Mr. G. Kivenson

Dr. W. H. Arnold

Mr. E. Anderson

Mr. D. Jacobs

Dr. D. E. Thomas

Mr. F. E. McLone
Dese April 23, 1962

From W. D. Allen - WANL

Subjuct Survey of Test Reactors

A survey of test reactors necessitated by the WTR shutdown has been completed. The irradiation experiments of interest involve high fluxes. for short times, and all but one require elevated specimen temperatures. The reactor capabilities investigated were as follows:

1) Ability to insert and remove capsules during reactor operation.

2) Thermal neutron fluxes of the order of $10^{14} \mathrm{nv}$.

3) Acceprability of capsules 2-inch or more in diameter.

The reactors that were contacted or investigated were as follows:

Materials Testing Reactor - This reactor is usually full and scheduling is difficult except for short-time rabbit irradiations.

Engineering Testing Reactor - Very little information was supplied and the impression is that scheduling in the reactor would be difficult.

Plum Brook Reactor - It is interesting to note that there would be no irradiation charges for work on NASA sponsored contracts. This reactor would be the most advantageous to WANL from many viewpoints (location, interest in NERVA programs, flux, availability, etc.). However, September 1, 1962 is the earliest anticipated date for full power operation, and this is subject to possible delays. 
General Electric Testing Reactor - They are anxious to have us use their reactor, as was exemplified by a visit from a coordinator of their aerospace interests. Their "trail-cable" facility appears to be most advantageous.

NRX Chalk River Reactor - They were very cooperative in sending information about their reactors. It appears, however, that considerable complications and/or delays could be encountered by using a Canadian reactor.

\section{Hanford Irradiation Facilities - We were informed that they will} "... accept only that irradiation work which cannot be carried out in commercial facilities..." and/or "... only that work which cannot be handled in Commission*owned test reactors."

A breakdown of the facilities applicable to the requirement of experiment insertion during reactor operation is presented in Table 1.

Consideration of all the factors involved has led to the conclusion that the Plum Brook Reactor would be the most advantageous for WANL irradiation work. However, because of the urgent need for certain data, the GETR trail-cable facility will be examined further.

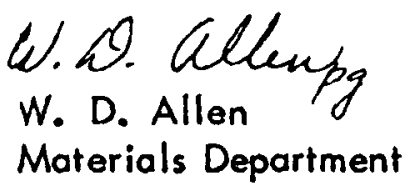

* The United States Atomic Energy Commission $\because$ 
Survey of Radiation Effects Testing Facilities

1. Introduction

In order to properly discuss the number and type of radiation effects testing facilities required to support the development of NERVA reactor and engine components and subsystems, it is felt that a classification by categories based on environmental and size considerations will be useful. The attached table itemizes seven categories and summarizes other pertinent data. It is realized that much of the information included in this table is based upon rather incomplete information and will be modified as the specific programs are finalized. However, it should prove adequate for performing a preliminary analysis of required reactor test facilities.

In discussing the various reactor test facilities, no attempt will be made to completely describe the available irradiation facilities, flux intensities, handling procedures, etc. This information is adequately covered in existing documents such as Battelle Memorial Institute REIC Report No. 16, entitled "Survey of Irradiation Facilities." Features having a direct bearing on possible NERVA applications, however, will be discussed where appropriate.

\section{Reactor Test Facilities}

2. I Category I and II Testing - The only reactor facility that will be capable of conducting tests at very high radiation intensities in combination with cryogenic temperatures is the NASA Plumbrook Reactor. This assumes, of course, that the Lockheed cryogenic facility in the Plumbrook Reactor can be made available for Category I and II component testing. Since the Plumbrook Reactor is not expected to be ready for experimental use before the Fall of 1962, it is felt that an initial screening program in either the Ground Test Reactor (GTR) or the Battelle Research Reactor would produce useful data. The $3 \mathrm{MW}$ GTR has an existing cryogenic system capable of accepting liquid hydrogen. The $2 \mathrm{MW}$ Battelle Reactor is presently installing a cryogenic system which should be completed by July 1962. Both of these reactors offer maximum fast neutron fluxes approximately two decades below the desired values. However, by exposing the components for sufficiently long periods of time, one can simulate the integrated fluxes that would be encountered during typical NERVA missions. Hence, one can establish whether or not these components can withstand such an environment without suffering any $+x$ significant permanent radiation damage.

2.2 Category III Testing - The Astronuclear Materials Department has recently completed a survey of reactor facilities capable of accommodating a high flux, high temperature irradiation program of various reactor materials. Attached is a memorandum prepared by Mr. Allen of the Materials Department summarizing the results of their survey. Their latest plans are to use 
WANL-TME-046

the 4" I.D. "trail cable" facility in the General Electric Test Reactor (GETR) until such time that they could gain access to the Plumbrook Reactor. The trail cable facility allows one to insert and withdraw instrumented capsules while the reactor is at full power $(30 \mathrm{MW})$. The expected flux intensities are as follows:

$$
\begin{array}{ll}
\text { Thermal Neutron Flux: } \sim 8 \times 10^{13} \mathrm{n} / \mathrm{cm}^{2}-\mathrm{sec} \\
\text { Neutron Flux> } 0.18 \mathrm{Mev:} \quad 3 \times 10^{13} \mathrm{n} / \mathrm{cm}^{2}-\mathrm{sec} \\
\text { Neutron Flux>0.50 Mev: } & 1 \times 10^{13} \mathrm{n} / \mathrm{cm}^{2}-\mathrm{sec} \\
\text { Neutron Flux> } 1.0 \mathrm{Mev}: & 0.7 \times 10^{13} \mathrm{n} / \mathrm{cm}^{2}-\mathrm{sec} \\
\text { Gamma Heating Rate: } & 1 \text { watt/gram }
\end{array}
$$

2.3 Category IV Testing - In order to perform tests on thermocouples and pressure transducers at the flux, tempera.i.n, and size conditions specified in Category IV, it is felt that either the Engineering Test Reactor(ETR) or the Plumbrook Reactor would have to be ufilized. Both of these reactors are capable of providing the necessary conditions. However, as pointed out previously, there is a serious question as to the time factor involved in getting the Plumbrook Reactor to full power and ready for experimental use. On the other hand, there might be a serious problem in getting into the ETR since all of the suitable irradiation facilities are presently occupied with long-term experimental programs (most of which are sponsored by the Navy.) These problems are currently being investigated in more detail.

2.4 Category V Testing - As in the case of Category IV testing, it is felt that either the ETR or the Plumbrook Reactor would have to be utilized to meet the requirements of Category $\vee$ Testing. However, because of the fact that neither of these test reactors could be used soon enough to avoid incurring unacceptable delays in the NERVA control system development program, lower-power reactors were also investigated which offered the following capabilities: in-core irradiation facilities, immediate access, and low-cost irradiation charges. Since the idea would be to use a lower-power reactor only until one could gain access to either the ETR or Plumbrook, capsule design, cooling systems, etc. would be kept as simple and inexpensive as possible.

One of the lower-power reactors that appears very attractive for initial testing is located at the Western New York Nuclear Research Center, Buffalo, New York. This IMW swimming pool reactor offers all of the capabilities mentioned above, plus it is relatively convenient to the Astronuclear Laboratory. On March 27, 1962, Mr. F. E. McLane and Mr. H. P. Kalapaca visited this facility and discussed a possible program with Dr. Lumb, Director of the Nuclear Research Center. It was felt that one of the major test requirements 
would be to maximize the fast neutron flux to which experiments are subjected. Hence, it appeared that a $3^{\prime \prime} \times 3^{\prime \prime}$ test void in the reactor core would be the optimum location. The estimated flux values in this location are: $4 \times 10^{12}$ fast neutrons $/ \mathrm{cm}^{2}-\mathrm{sec}$ and $8 \times 10^{7} \mathrm{R} / \mathrm{hr}$ gamma dose rate. The charge for using this position would be $\$ 20.00 / \mathrm{hr}$. In addition to the reactor service, they offer hot cell and warm lab facilities for post-irradiation analysis; machine shop facilities for capsule buildup; and dosimetry and counting room facilities for mapping the radiation environment.

\subsection{Category VI Testing - The items which fall into Category VI} could be tested in a large number of different reactor facilities. Large numbers of components could be tested simultaneously on one of the cabledriven dollies in the GTR. For experiments requiring higher fluxes but smaller volumes, the Buffalo or Battelle facilities could be readily utilized.

\subsection{Category VII Testing - The necessity of providing large volume} test voids with cryogenic capabilities imposes a unique requirement with respect to existing reactor facilities. It is doubtful whether the present capacity of the GTR cryogenic system would meet the requirements of Category VII testing. However, modification of this system could probably be accomplished with a reasonable expenditure of time and money. This work could also be accomplished at the Lockheed Georgia Nuclear Test Reactor. However, in this case, one would face the additional problems of reactivating a reactor facility and providing the entire cryogenic system.

\section{Other Reactor Facilities Surveyed}

In addition to the reactors already discussed, a number of other facilities have been surveyed. These facilities have been tentatively eliminated from further consideration for the reasons cited below.

-3. I Materials Testing Reactor - Like the ETR, suitable irradiation facilities in the MTR are presently occupied with long-term programs. Furthermore, the maximum radiation intensities available in these facilities do not meet the requirements of Categories I through $V$. The only Category it could satisfy would be VI. Taking all factors into consideration, it is felt that Category VI testing could be more easily and cheaply accomplished in facilities such as Buffalo or the GTR.

\subsection{Oak Ridge Research Reactor - A contact with the Oak Ridge} National Laboratory revealed that only limited space was available on the side of the reactor pressure vessel. Furthermore, the flux intensities at this location were not high enough to warrant further consideration.

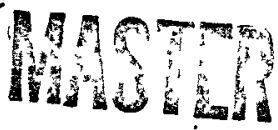

3.3 Sandia Engineering Reactor Facility (SERF) - Mr. J. L. Colp of the Radiation Effecis Division, Sandia Corporation, was contacted in order to determine the status of the SERF reactor. It was learned that they do not expect to be at full power before October 1962. 
Table 1

IRRADIATION CAPABILITIES OF REACTORS INVESTIGATED

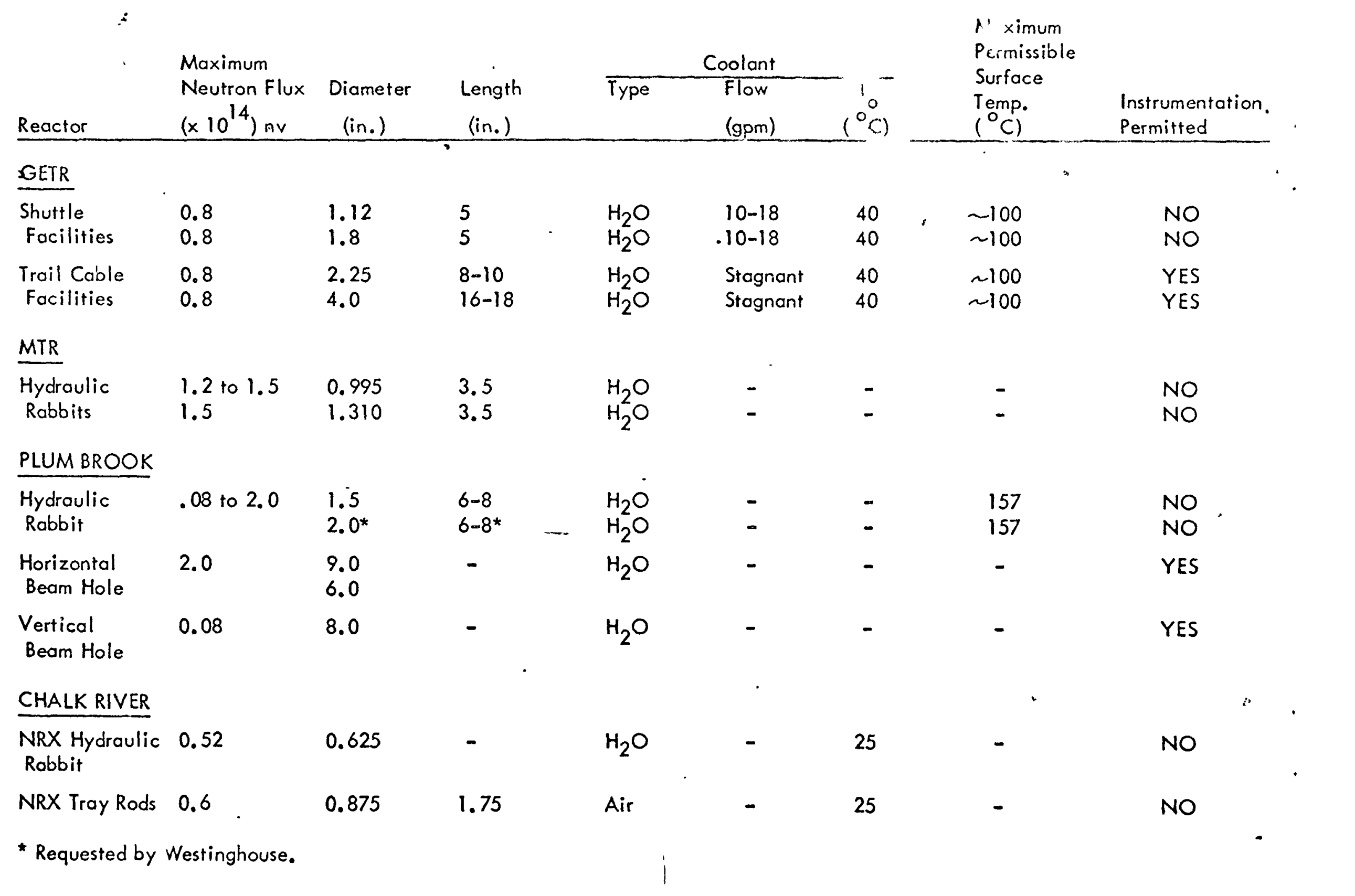


.



